\title{
Analysis of Location quotient of major industries in Qinghai Province
}

\author{
WenYu ${ }^{1, *}$ \\ ${ }^{1}$ Qinghai postgraduate, research direction is rural regional development.
}

\begin{abstract}
This paper selects the location quotient analysis method to analyze the current situation of the three major industries in Qinghai.This paper expounds the characteristics of the current industrial situation in this region, finds out the existing problems, and puts forward some Suggestions on the adjustment of regional industrial structure.
\end{abstract}

\section{Analysis on the status quo of three industries in Qinghai Province}

\subsection{The general situation of the three industries} According to the evolution law of industrial structure, with the development of regional economy, the proportion of the primary industry will gradually decline, the proportion of the secondary industry will show a trend of rapid increase, slow increase, constant and gradual decline with the industrialization process, and the proportion of the tertiary industry will continue to rise.

From 1999 to 2019, Qinghai's GDP grew from 23.9 billion yuan to 296.5 billion yuan. The growth rate of the primary industry in Qinghai province is generally lower than the growth rate of the regional GDP, and the output value proportion has dropped from $17.56 \%$ to $10.10 \%$. From 1999 to 2019 , the growth rate of the secondary industry in Qinghai was generally higher than the growth rate of regional GDP, and the output value accounted for $43.52 \%$, up from $39.28 \%$.In 2019, the growth rate of the tertiary industry in Qinghai was higher than that of the regional GDP, and the output value accounted for $50.70 \%$ from $43.16 \%$ in 1999 to 2019 .

\subsection{The internal development status of each industry}

\subsubsection{The internal structure of the primary industry}

The total output value in 1999 was 5.902 billion yuan, among which the output value of agriculture, forestry, animal husbandry and fishery was $29.3,1.4,28.2$ and 0.1 billion yuan respectively.From 1999 to 2019 , the total output value of agriculture, forestry, animal husbandry and fishery increased from 5.902 billion yuan to 45.435 billion yuan. Qinghai province agricultural output value of 18.125 billion yuan in $2019,39.9 \%$ of the total output value of ecological-economic, qinghai province forestry output value is 1.125 billion yuan, $2.5 \%$ of the total output value of ecological-economic, qinghai province animal husbandry output value is 25.081 billion yuan, $55.2 \%$ of the total output value of ecological-economic, an increase of $7.7 \%$ over the previous year, industry contribution rate reached $5.18 \%$, to the pull rate of $0.37 \%$ of the total cost of the production of qinghai province, qinghai province fishery output value is 392 million yuan, because geographical environment factors of fishery only $0.01 \%$ of the total output value of animal husbandry fishery.

\subsubsection{The internal structure of the secondary industry}

In 1999, the total output value of the secondary industry of Qinghai province was 9.403 billion yuan. By 2019, the total output value of the secondary industry is 115.975 billion yuan, accounting for $39.1 \%$ of the total output value of the province. The contribution rate of the secondary industry to the total output value of Qinghai Province has reached $54.8 \%$, driving the growth of the total output value by 2.2 percentage points.In 2019, the added value of the manufacturing industry increased by $8.8 \%$, the added value of the mining industry increased by $3.1 \%$, and the added value of the construction industry in Qinghai reached 34.226 billion yuan, up by $5.2 \%$. The proportion of the construction industry in the regional GDP in Qinghai was higher than the national level.

\subsubsection{Internal structure of tertiary industry}

From 1999 to 2019, the total output value of the tertiary industry increased from10.332billion yuan to 150.43 billion yuan. The tertiary industry includes transportation,

* Corresponding author: ${ }^{3} 379616970 @ q q . c o m$ 
warehousing and postal services, wholesale and retail, accommodation and catering, tourism, real estate and other related industries. In 2019, the total revenue of tourism reached 56.133 billion yuan, up by $20.4 \%$. The added value of wholesale and retail businesses reached 16.083 billion yuan, up $4.5 \%$ from the previous year.Transportation, warehousing and postal services added 12.318 billion yuan, up $0.9 \%$. The added value of the accommodation and catering industry reached 5.075 billion yuan, up $3.2 \%$. The added value of the real estate sector reached 12.749 billion yuan, up 3.9\%.

\subsection{The development of three industries in different regions of Qinghai Province}

In 2019, the GDP of Xining city, Qinghai Province, reached 138.289 billion yuan, up $7.5 \%$. The added value of the primary industry reached 4.803 billion yuan, up by $4.2 \%$. The added value of the secondary industry reached 49.654 billion yuan, up by $6.1 \%$. The added value of the tertiary industry reached 84.417 billion yuan, up 9.3\%. The ratio of three industrial structures was 3.6:36.4:60.1.

The GDP of Haidong is 48.773 billion yuan. By industry, the added value of the primary industry is 7.044 billion yuan, up by $5.2 \%$. The added value of the secondary industry reached 18.492 billion yuan, up $9 \%$. The added value of the tertiary industry reached 23.236 billion yuan, up by $4.7 \%$. The added value of the three industries accounted for $14.44 \%, 37.92 \%$ and $47.64 \%$ of the city's GDP, respectively.

Haibei Tibetan Autonomous Prefecture's GDP in 2019 was 9.17 billion yuan.By industry, the added value of the primary industry was 2.562 billion yuan, up by $4.5 \%$. The added value of the secondary industry was 2.2 billion yuan, up by $7.6 \%$. The added value of the tertiary industry was 4.408 billion yuan, up $0.5 \%$. The ratio of three industries was 27.9:24.0:48.1.

The GDP of Huangnanzhou reached 10.095 billion yuan. Among them, the added value of the primary industry was 2.606 billion yuan, up by $4.5 \%$. The added value of the secondary industry reached 2.624 billion yuan, up $9.7 \%$. The added value of the tertiary industry was 4.865 billion yuan, up $8.2 \%$. The tertiary industrial structure is $25.8: 25.9: 48.2$.

The sizhou's GDP is 17.466 billion yuan. Of this, the added value of the primary industry was 4.359 billion yuan, up $4.6 \%$. The added value of the secondary industry reached 7.393 billion yuan, up $10.2 \%$. The added value of the tertiary industry reached 5.714 billion yuan, up $3.6 \%$. The proportion of the three industries was $25.0: 42.3: 32.7$.

The gross product of Guoluo prefecture was 461,800 yuan, with a year-on-year growth of $7.2 \%$. Among them, the added value of the primary industry was 84,000 yuan, with a year-on-year growth of $3.8 \%$. The added value of the secondary industry was 161,000 yuan, with a yearon-year growth of $10.4 \%$. The added value of the tertiary industry reached 217,000 yuan, up $6.5 \%$ year on year.

The GDP of Yushu prefecture reached 5.982 billion yuan, up by $5.1 \%$ year-on-year. By industry, the added value of the primary industry increased by $3.7 \%$ year-on- year to 3.444 billion yuan.The added value of the secondary industry reached 542 million yuan, with a year-on-year growth of $4.0 \%$. The added value of the tertiary industry reached 1.996 billion yuan, a year-onyear increase of $7.7 \%$.

The annual GDP of Haixi prefecture was 672.17, with a year-on-year growth of $7.5 \%$, of which the primary industry was 3.523 billion yuan, with an increase of $5.6 \%$. The secondary industry reached 46.353 billion yuan, up $8.2 \%$. The tertiary industry totaled 17.365 billion yuan, up $6.2 \%$. The contribution of the three industries to GDP was $4.7 \%, 72.5 \%$ and $22.8 \%$.

\section{Calculation and Analysis of location quotient of three industries in Qinghai Province}

Location quotient is a basic analytical method to evaluate regional competitive industries.Location quotient, also known as specialization rate, was first proposed by Hargate and applied in location analysis. ${ }^{[1]}$ Formula is as follows:

$$
Q=\frac{j_{1}}{j_{2}} \div \frac{b_{1}}{b_{2}}
$$

\subsection{Calculation and analysis of Location quotient of Qinghai primary industry}

In the primary industry, according to the traditional statistical division, it is mainly divided into agriculture, forestry, animal husbandry and fishery. By consulting the data of national and Qinghai statistical yearbooks and using the calculation formula of location quotient, the value was calculated and sorted out (Table 1).

Table 1. Location quotient of primary industry in Qinghai province from 2015 to 2019 .

\begin{tabular}{lcccc}
\hline & agricultural & Forestry & $\begin{array}{c}\text { Animal } \\
\text { husbandry }\end{array}$ & fisheries \\
\hline 2015 & 0.85 & 0.54 & 1.76 & 0.09 \\
\hline 2016 & 0.88 & 0.56 & 1.71 & 0.09 \\
\hline 2017 & 0.84 & 0.55 & 1.87 & 0.09 \\
\hline 2018 & 0.77 & 0.54 & 2.11 & 0.08 \\
\hline 2019 & 0.75 & 0.53 & 2.07 & 0.09
\end{tabular}

By calculating and comparing the location-quotient value of the primary industry of Qinghai province from 2015 to 2019, it can be concluded that the locationquotient value of the agriculture of Qinghai province is less than 1 and has no comparative advantage. Forestry location quotient is less than 1 , there is no comparative 
advantage. Animal husbandry location quotient is greater than 1. Compared with the whole country, animal husbandry in Qinghai province has obvious advantages, and it can be used as the development of advantageous industries in Qinghai Province.The fishery location quotient is less than 0.1 , which is in an absolute inferior position.

\subsection{Calculation and analysis of Location quotient of Qinghai secondary industry}

In the secondary industry, through the National statistical Yearbook and qinghai statistical yearbook, mining, manufacturing and construction data of the whole country and Qinghai were selected and calculated ( Table 2).

Table 2. Qinghai secondary industry location quotient from 2015 to 2019

\begin{tabular}{cccc}
\hline & $\begin{array}{c}\text { The } \\
\text { mining } \\
\text { industry }\end{array}$ & $\begin{array}{c}\text { manufacturi } \\
\text { ng }\end{array}$ & $\begin{array}{c}\text { The } \\
\text { construction } \\
\text { industry }\end{array}$ \\
\hline 2015 & 1.50 & 0.69 & 2.00 \\
\hline 2016 & 1.10 & 0.63 & 1.84 \\
\hline 2017 & 1.85 & 0.94 & 1.83 \\
\hline 2018 & 2.13 & 0.41 & 1.91 \\
\hline & & & \\
\hline
\end{tabular}

In Table 2, from the perspective of location quotient of the secondary industry in Qinghai province from 2015 to 2019 , the location quotient value of mining industry and construction industry is greater than 1, indicating that these industries have advantages to a certain extent and show strong competitiveness of this industry.Qinghai's manufacturing sector, which relies heavily on construction and mining, is below the national average. The manufacturing industry in Qinghai province has a high operating cost, low production efficiency and underdeveloped production technology.

\subsection{Calculation and analysis of location quotient of Qinghai tertiary industry}

In the tertiary industry, selected transportation, warehous ing and postal industry, wholesale and retail industry, ac commodation and catering industry, tourism, real estate $i$ ndustry and other related industries.Calculated values ( $\mathrm{T}$ able 3)

Table3. Qinghai tertiary industry location quotient from 2015 to 2019

\begin{tabular}{|c|c|c|c|c|c|}
\hline & $\begin{array}{l}\text { Accom } \\
\text { modati } \\
\text { on and } \\
\text { caterin } \\
\mathrm{g}\end{array}$ & $\begin{array}{l}\text { The } \\
\text { real } \\
\text { estate }\end{array}$ & $\begin{array}{c}\text { Whole } \\
\text { sale } \\
\text { and } \\
\text { Retail }\end{array}$ & $\begin{array}{c}\text { Transportati } \\
\text { on, } \\
\text { warehousing } \\
\text { and postal } \\
\text { services }\end{array}$ & $\begin{array}{l}\text { The } \\
\text { touris } \\
\mathrm{m} \\
\text { indust } \\
\text { ry }\end{array}$ \\
\hline 2015 & 1.23 & 0.45 & 0.80 & 1.02 & 2.48 \\
\hline 2016 & 1.15 & 0.39 & 0.77 & 0.96 & 2.64 \\
\hline 2017 & 1.16 & 0.38 & 0.76 & 0.97 & 2.92 \\
\hline 2018 & 1.12 & 0.40 & 0.73 & 0.92 & 3.16 \\
\hline 2019 & 1.01 & 0.35 & 0.62 & 1.02 & 3.73 \\
\hline
\end{tabular}

The third industry, in addition to the tourism and hotel and catering industry has comparative advantage, whether in real estate, wholesale and retail, still belongs to the modern service industry of transportation, warehousing and postal service, the location quotient are less than 1 , industry, belong to the disadvantages of this from a certain extent, shows that qinghai province as a whole in the third industry development is relatively backward.

\subsection{Calculation and analysis of location quotient of major industries in Cities and towns of Qinghai Province}

By consulting the Statistical yearbook of Qinghai Province, data of six provinces, two cities and major industries of Qinghai Province were selected, and location quotient formula was used to calculate the value (Table 4).

Table 4. In 2018, the position traders in the second urban districts of Six prefectures in Qinghai Province

Xining Haidong Haibei Huangnan Hainan Guoluo Yushu Haixi


Agriculture,

\begin{tabular}{|c|c|c|c|c|c|c|c|}
\hline $\begin{array}{l}\text { forestry, animal } \\
\text { husbandry and } \\
\text { The mining } \\
\text { industry }\end{array}$ & 0.38 & 1.50 & 2.89 & 2.82 & 2.62 & 1.93 & 6.05 \\
\hline
\end{tabular}

\begin{tabular}{|c|c|c|c|c|c|c|c|c|}
\hline manufacturing & l & 0.26 & 0.26 & 1 & 0.05 & 0.74 & I & 2.05 \\
\hline $\begin{array}{l}\text { The } \\
\text { construction } \\
\text { industry }\end{array}$ & 1.72 & 1.40 & 0.27 & 0.28 & 0.82 & 1.66 & / & 2.98 \\
\hline $\begin{array}{l}\text { Accommodation } \\
\text { and catering }\end{array}$ & 0.88 & 1.48 & 0.71 & 1.14 & 0.68 & 2.29 & 0.84 & 0.68 \\
\hline $\begin{array}{l}\text { The real estate } \\
\text { industry }\end{array}$ & 0.58 & 0.99 & 1.34 & 1.14 & 0.92 & 0.52 & 0.52 & 0.44 \\
\hline $\begin{array}{l}\text { Wholesale and } \\
\text { Retail }\end{array}$ & 1.09 & 0.62 & 0.62 & 0.44 & 0.71 & 0.54 & 0.03 & 0.29 \\
\hline $\begin{array}{l}\text { Transportation, } \\
\text { warehousing } \\
\text { and postal } \\
\text { services }\end{array}$ & 1.44 & 0.57 & 0.60 & 0.31 & 0.36 & 1.03 & 0.79 & 0.06 \\
\hline
\end{tabular}

The agriculture, forestry, animal husbandry and fishery of Qinghai province are mainly in the west, among which the pastoral output value of Guoluo, Yushu and Huangnan accounted for more than $70 \%$ of the total agricultural output value of the qinghai region, which belongs to the typical pastoral production zone.

The location quotient of mining and manufacturing industries in Haixi was the highest, which was 2.05 and 2.98 , respectively.Haixi is rich in mineral resources, with lake salt, potassium salt, magnesium salt, lithium, strontium, asbestos, mirabilite and limestone reserves ranking the first in China, and bromine and boron reserves ranking the second.Secondly, abundant reserves of petroleum and natural gas, large annual output of ore and strong resource advantages provide a material basis for the development of oil and natural gas exploitation industry.

Among the tertiary industries in Qinghai province, Haibei Prefecture has the highest location quotient for accommodation and catering industry. Haibei Prefecture has an advantageous geographical location, and tourism has promoted the development of the tertiary industry in Haibei Prefecture to a certain extent. As the provincial capital of Qinghai Province, Xining is a typical migrant city with multiple democracies and religions coexisting together. It is the only central city on the Qinghai-Tibet Plateau with a population of more than one million. Therefore, Compared with other cities and cities in Qinghai province, Xining has certain development advantages in the real estate industry, wholesale and retail industry, transportation, storage and postal service.

\section{Conclusions and Recommendations}

According to the above analysis, it can be found that Qinghai province is a big province with high resource carrying capacity, and it has a comparative advantage especially in mineral resources.It also has some characteristics in agriculture, animal husbandry and tourism resources. 
The primary industry should innovate its thinking, change its development philosophy, optimize the operation and development model of agriculture and animal husbandry, and form an overall thinking for the comprehensive development of agriculture and animal husbandry. The secondary industry takes up a large proportion in the economic development of Qinghai Province, which has the problems of high production cost and low resource utilization rate. In order to promote the adjustment of industrial structure, Qinghai must constantly increase investment in science and technology, innovate science and technology, and promote the application and transformation of science and technology in the process of industrialization. In order to promote the development of the tertiary industry, it is necessary to create a good environment for the development of the service industry and formulate the development plan of the service industry and its key industries. In terms of advantageous industrial tourism, we should strengthen tourism investment and development, enrich tourism products and enhance tourism characteristics.

All regions of Qinghai province should actively develop advantageous industries and make full use of advantageous resources. Xining and Haidong should further establish the status of economic center and accelerate the overall development of service industry. Haibei region should focus on the development of coal industry chain, continue to give play to resource advantages, mining industry as the fundamental driving force for development. Hainan and Huangnan should vigorously develop characteristic agriculture and tourism, especially the agricultural and mining deep processing industries with relative regional advantages. Yushu prefecture should focus on promoting sustainable and efficient development of animal husbandry and increase investment in infrastructure construction.

\section{References}

1. Ding, S, X. (2012) Regional economics.Qinghai Peo ple's Publishing House, Qinghai .

2. Wu, Z, L. (2014) Research on the Development ma rket of Characteristic advantageous industries in Qin ghai Province.

3. Lan, H. (2018) Analysis on the development status and Advantages and Disadvantages of Qinghai tourism industry.

4. Hang, J, X. (2018) Based on the location quotient analysis of characteristic advantageous industries in Qinghai Province. 